\title{
GAUSSIAN MIXTURE MODEL UNTUK PENGHITUNGAN TINGKAT KEBERSIHAN SUNGAI BERBASIS PENGOLAHAN CITRA
}

\author{
Bayu Charisma Putra ${ }^{1}$, Yunita Nur Afifah ${ }^{2}$ \\ Teknik Informatika, Fakultas Teknik \\ Universitas Maarif Hasyim Latif, Sidoarjo, Indonesia \\ e-mail : 1bayu_charisma@dosen.umaha.ac.id,2yunitanurafifah02@gmail.com \\ Diterima: 18 April 2018. Disetujui : 15 Juni 2018. Dipublikasikan : 29 Juni 2018

\section{ABSTRAK}

Banjir adalah salah satu permasalahan yang paling sering terjadi pada hampir setiap musim hujan. Salah satu penyebab banjir adalah terhambatnya aliran sungai akibat sampah yang menumpuk, sehingga air sungai yang seharusnya mengalir ke hilir akan meluber ke pemukiman. Hal tersebut tentunya harus mendapat perhatian lebih dari dinas terkait, salah satunya adalah dengan menggali informasi sungai mana saja yang menjadi prioritas berdasarkan kondisi kebersihannya. Seiring berkembangnya era digital, informasi tersebut dapat diperoleh dengan menggunakan sebuah alat. Dalam jurnal ini akan dibahas bagaimana memperoleh informasi tingkat kebersihan sungai dengan metode Gaussian Mixture Model (GMM) berbasis pengolahan citra. Untuk mencapai tujuan tersebut diperlukan beberapa tahap. Tahap pertama adalah mendeteksi sampah yang ada pada sungai dengan proses background subtraction menggunakan metode GMM. Output dari proses background subtraction adalah kumpulan gambar yang hanya memiliki dua intensitas cahaya yang bertujuan untuk membedakan background dan foreground. Masing-masing gambar tersebut selanjutnya di-filter menggunakan metode Median Filter untuk mengurangi gangguan pada gambar (noise) dan lebih mempertajam hasil deteksi. Terakhir adalah penghitungan tingkat kebersihan sungai berdasarkan prosentase sampah pada sungai di dalam ROI (Region of Intereset). Selanjutnya perhitungan tersebut disimulasikan dengan aplikasi berbasis desktop dengan bahasa pemrograman JAVA.

Kata kunci: banjir, deteksi sampah, gaussian mixture model, median filter, pengolahan citra, java

\section{PENDAHULUAN}

Hampir setiap musim penghujan di Indonesia mempunyai masalah yaitu banjir. Salah satu faktor banjir adalah terhambatnya aliran air sungai akibat dari banyaknya sampah yang menumpuk seperti yang ditampilkan pada Gambar

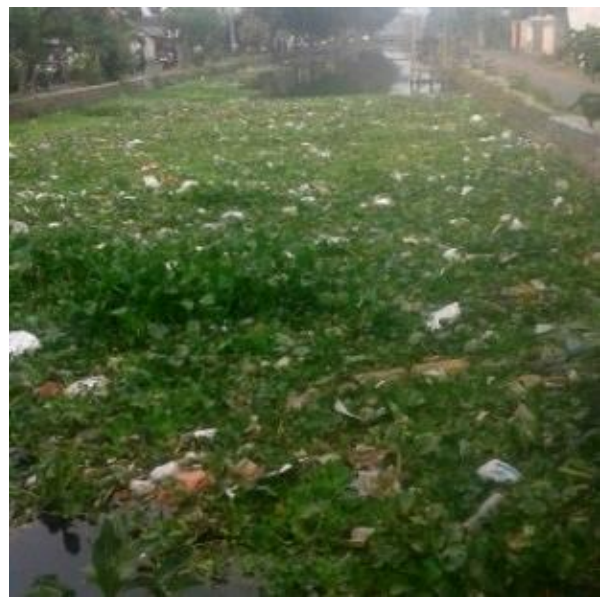

1. Dengan mengetahui informasi dasar seperti tingkat kebersihan sungai berdasarkan banyaknya sampah di sungai, dinas terkait dapat dengan sigap mengatasinya sehingga faktor tersebut dapat diminimalisir.

Pesatnya perkembangan teknologi di semua aspek seperti saat ini sangat mendukung

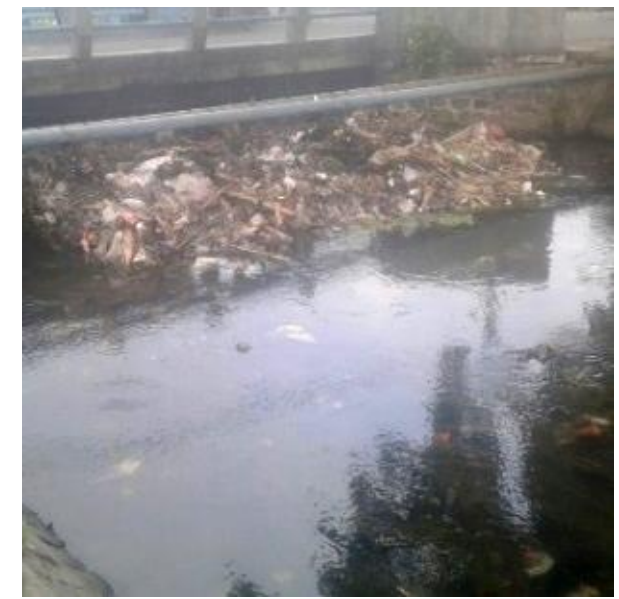

Gambar 1. Aliran air sungai yang terhambat 

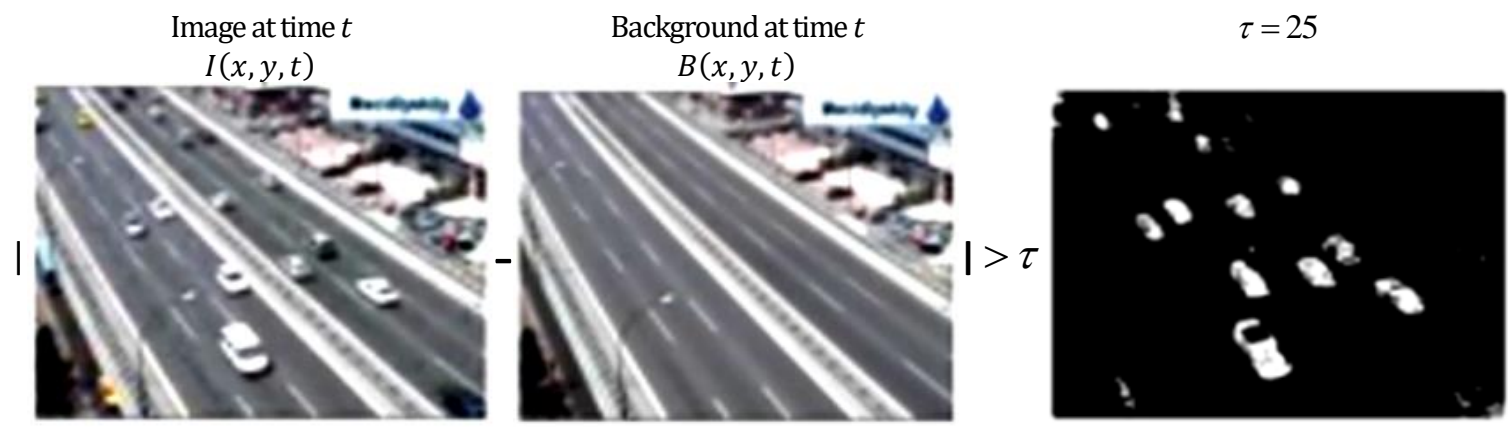

Gambar 2. Proses Background Subtraction

penyelesaian masalah secara komputasi. Dengan menggunakan data input berupa video air sungai yang mengalir, penghitungan tingkat kebersihan sungai dengan menggunakan pengolahan citra dapat menjadi pilihan yang akan menghemat tenaga, waktu, dan biaya. Video akan dijadikan sebagai sumber untuk memperoleh obyek yang bergerak dengan algoritma Background Subtraction.

Background Subtraction merupakan salah satu algoritma yang dapat memproses serangkaian citra pada video digital untuk mendapatkan obyek foreground dari model background yang telah ditentukan sebelumnya. Obyek foreground adalah segala sesuatu yang dideteksi dari hasil pengurangan citra pada waktu $t$ dengan model background. Hasil tersebut dapat digunakan untuk mendeteksi gerak objek (Bharti, 2013).

Rosenberg $\mathrm{C}$ melakukan perbandingan dari 7 metode Background Subtraction; Basic, Min Max Inter-Frame Difference, One Gaussian(1-G), Eigen Backgrounds (Eigen), Kernel Density Estimation (KDE), Codebook (CBRGB), dan Gaussian Mixture Model (GMM). Dari penelitan tersebut diperoleh kesimpulan bahwa metode GMM memiliki tingkat akurasi yang tinggi dengan berbagai kondisi input video; static, multimodal, maupun noise background serta memiliki waktu komputasi dan kebutuhan memori yang lebih efisien dibandingkan metode yang lain (Benezeth, Jodoin, Emile, Laurent, \& Rosenberger, 2010).

Berdasarkan paparan diatas, dalam jurnal ini membahas tentang bagaimana cara menghitung tingkat kebersihan dengan menggunakan GMM berbasis pengolahan citra digital. Tahap pertama yang dilakukan adalah deteksi sampah yang mengalir pada sungai. Untuk lebih meningkatkan tingkat akurasi deteksi, akan dilakukan filtering dengan menggunakan metode Median Filter. Terakhir adalah penghitungan tingkat kebersihan sungai berdasarkan prosentase sampah dengan sungai pada ROI (Region of Intereset).

\section{METODE PENELITIAN}

\section{Background Subtraction}

Background Subtraction adalah proses untuk mendapatkan foreground object (obyek yang bergerak) dari serangkaian citra. Foreground diperoleh dengan melakukan pengurangan frame pada waktu $t$ dengan background model dari video, kemudian hasil pengurangan tersebut dibandingkan dengan suatu nilai ambang batas (threshold) tertentu. Contoh proses background subtraction diberikan pada Gambar 2. Persamaan (1) dan persamaan (2), adalah representasi dari penjelasan tersebut dalam bentuk matematis.

$$
\begin{gathered}
|I(x, y, t)-B(x, y, t)|=d(x, y, t) \\
f(x, y, t)= \begin{cases}1, & \text { Jika } d(x, y, t) \geq \tau, \\
0, & \text { lainnya }\end{cases}
\end{gathered}
$$

Dengan $I(x, y, t)$ merupakan intensitas dari citra $(x, y)$ pada frame $t, B(x, y, t)$ merupakan intensitas dari background citra $(x, y)$ pada frame $t$, $d(x, y, t)$ merupakan hasil pengurangan intensitas dari background citra terhadap intensitas dari citra pada frame $t, \tau$ merupakan ambang batas atau threshold, dan $f(x, y, t)$ adalah intensitas dari foreground citra.

\section{Gaussian Mixture Model}

Gaussian Mixture Model (GMM) merupakan salah satu metode yang paling baik untuk mendapatkan foreground object (Background Subtraction). GMM adalah tipe model kepadatan yang terdiri dari banyak komponen berupa fungsi gaussian. Komponen fungsi gaussian tersebut terdiri dari weight yang berbeda untuk menghasilkan beberapa model kepadatan. Model dari Gaussian Mixture terbentuk dari warna-warna pada piksel berdasarkan waktu. Model tersebut terbagi menjadi 2 bagian, model yang mencerminkan foreground yang dalam penelitian ini adalah sampah dan model yang mencerminkan background.

Menurut Amaluddin dkk (Amaluddin, Muslim, \& Naba, 2015) Jumlah model GMM yang digunakan mempengaruhi jumlah model background. Semakin sedikit jumlah model GMM yang digunakan maka akan semakin sedikit pula model background yang dimiliki suatu piksel. GMM memproses tiap piksel pada citra, baik citra 
tersebut berupa skalar (citra grayscale) maupun vektor (citra berwarna).

Menurut Amaluddin dkk (Amaluddin et al., 2015) terdapat beberapa tahapan dalam pemilihan distribusi yang mencerminkan background. Tahapan-tahapan tersebut adalah :

1. Pencocokan input terhadap distribusi.

Pada proses ini input yang berupa intensitas dari warna dibandingkan dengan semua distribusi, kemudian dipilih distribusi yang paling sesuai. Suatu intensitas piksel input dikatakan sesuai dengan suatu distribusi jika nilai intensitas piksel tersebut masuk dalam range 2.5 simpangan baku dari distribusi tersebut. Untuk pencocokan input digunakan persamaan (3).

$$
\mu_{k}-\left(2.5 \times \sigma_{k}\right)<X_{t}<\mu_{k}+\left(2.5 \times \sigma_{k}\right)
$$

2. Memperbarui parameter

Pada proses ini dilakukan pembaharuan beberapa parameter GMM, dimana parameter tersebut akan digunakan untuk mengolah intensitas piksel atau input selanjutnya. Nilai yang di-update terdiri dari weight, mean, dan standard deviation. Nilai weight di-update menggunakan persamaan (4). Nilai mean diupdate menggunakan persamaan (6) dengan $\rho$ diberikan pada persamaan (5). Nilai standard deviation di-update menggunakan persamaan (7). Persamaan-persamaan tersebut akan diberlakukan pada masing-masing piksel $(i, j)$.

$$
\begin{gathered}
\omega_{k, t}=(1-\alpha) \omega_{k, t-1}+\alpha\left(M_{k, t}\right) \\
\rho=\frac{\alpha}{\omega_{k, t}} \\
\mu_{k, t}=(1-\rho) \mu_{k, t-1}+\rho X_{t} \\
\sigma_{k, t}^{2}=(1-\rho) \sigma_{k, t-1}^{2}+\rho\left(X_{t}-\mu_{k, t}\right)\left(X_{t}-\mu_{k, t}\right)
\end{gathered}
$$

Dimana $\omega_{k, t}$ adalah bobot dari gaussian ke- $k$ pada frame $t, \alpha$ adalah learning rate, $M_{k, t}$ adalah sebuah parameter yang mempunyai nilai 0 untuk model yang tidak cocok dan 1 untuk model yang cocok, $\mu_{k, t}$ adalah mean dari gaussian ke- $k$ pada frame $t$, dan $\sigma_{k, t}$ adalah simpangan baku dari gaussian ke- $k$ pada frame $t$. Setelah parameter bobot di-update, terdapat tahap normalisasi dari bobot, yang bertujuan agar total dari bobot semua distribusi tepat 1 . Sementara mean dan simpangan baku di-update hanya jika ada nilai piksel yang cocok dengan distribusi tersebut.

3. Pemilihan Distribusi Background

Tujuan dari proses ini adalah memilih model Gaussian yang paling menyerupai background. Proses pertama model Gaussian diurutkan berdasarkan $\frac{\omega}{\sigma^{2}}$. Distribusi yang paling menyerupai background berada diurutan paling atas dan yang paling tidak menyerupai background ada di bawah yang nantinya digantikan oleh distribusi yang lain. Untuk memilih B distribusi pertama yang dijadikan distribusi background digunakan persamaan (8), dengan $T$ adalah nilai ambang batas yang telah ditentukan sebelumnya.

$$
B=\operatorname{argmin}_{b}\left(\sum_{k=1}^{b} \omega_{k}>T\right)
$$

\section{Median Filter}

Prinsip kerja dari metode median filter adalah dengan cara mengganti nilai intensitas dari tiap piksel dengan nilai median dari piksel-piksel tetangganya. Pola jangkauan piksel-piksel tetangga disebut dengan window yang mana telah ditentukan sebelumnya. Nilai median dihitung dengan melakukan sorting pada bagian window dan piksel itu sendiri. Hasil output dari median filter adalah frame dengan intensitas yang diperoleh dari nilai-nilai median tersebut. Proses tersebut dapat digambarkan pada Gambar 3

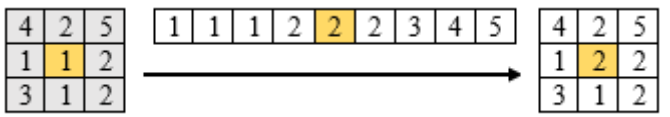

Gambar 3. Proses median filter

\section{Object Detection}

Pada penelitian ini, algoritma deteksi obyek yang digunakan adalah pixel connected yaitu dengan memeriksa semua piksel tetangganya di dalam area ROI yang sebelumnya telah diinputkan. Terdapat dua proses pada deteksi obyek yaitu mencari salah satu piksel dari suatu obyek yang bergerak dan mencari seluruh piksel dari obyek tersebut secara rekursif. Gambar 4 menjelaskan tentang proses tersebut.
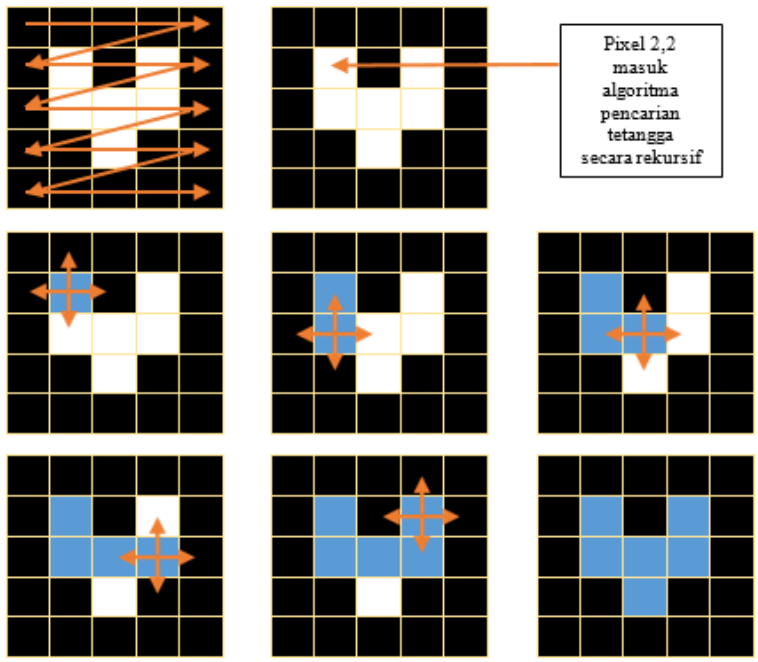

Gambar 4. Proses deteksi obyek

\section{HASIL DAN PEMBAHASAN}

Berdasarkan metode penelitian yang dijelaskan sebelumnya, untuk mendapatkan output 
yaitu tingkat kebersihan sungai, akan dilakukan simulasi menggunakan aplikasi yang telah dibuat dengan tahapan seperti yang ditunjukkan pada Gambar 5.

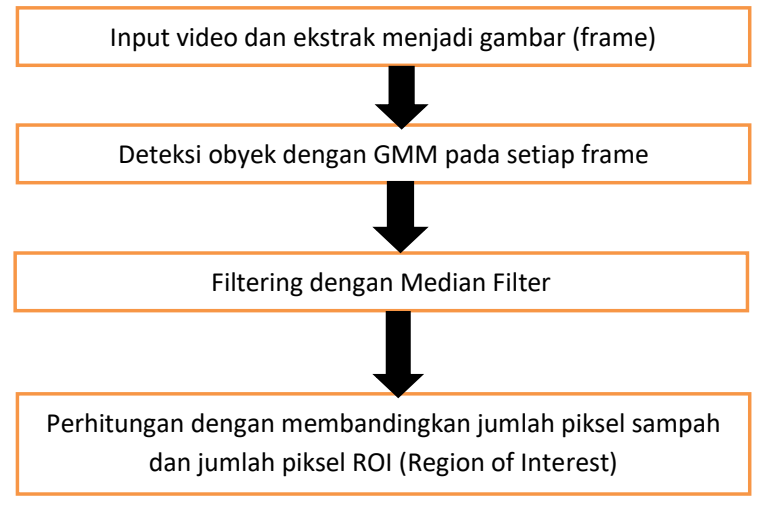

Gambar 5. Diagram proses perhitungan tingkat kebersihan sungai.

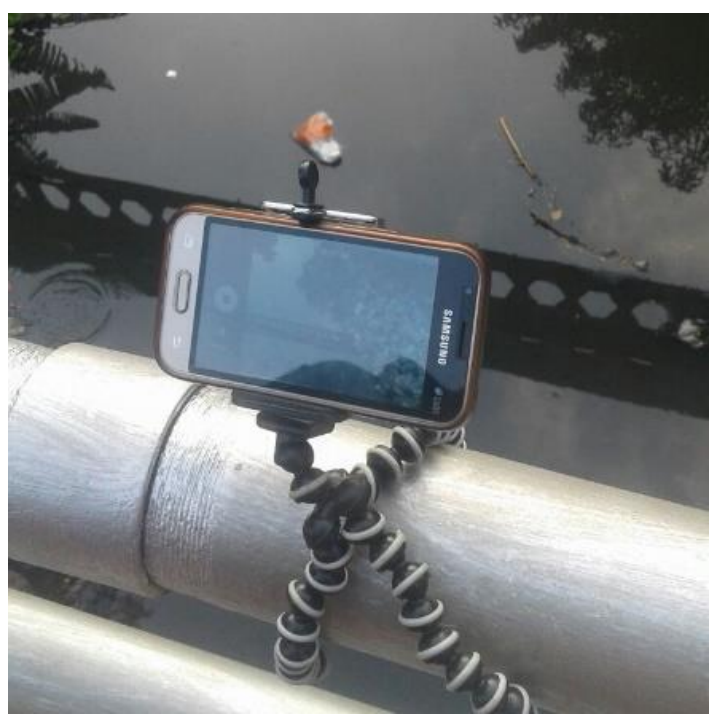

Gambar 6. Cara pengambilan data input, yaitu melalui kamera smartphone.

Data berupa video diambil dari atas jembatan. Alat untuk mengambil video terdiri dari sebuah smartphone dan sebuah octopus sebagai kaki. Smartphone dikaitkan pada octopus dan octopus dikaitkan pada pegangan jembatan. Pengambilan data dapat dilihat pada Gambar 6.
Dalam pengambilan data, kamera yang digunakan harus dalam posisi diam atau tidak bergerak. Hal tersebut dikarenakan proses background subtraction membutuhkan posisi piksel background yang sama pada setiap frame dari video. Kamera juga harus mencakup keseluruhan lebar sungai untuk memperoleh tingkat akurasi yang layak.

Simulasi dilakukan dengan bantuan sebuah aplikasi desktop yang dibuat dengan bahasa pemrograman JAVA. Aplikasi juga dibantu oleh sebuah library bernama OpenCV yang berfungsi untuk proses pengolahan citra pada JAVA. Tampilan muka pada aplikasi dapat dilihat pada Gambar 7.

Tahap pertama, tentukan ROI terlebih dahulu. Hal ini bertujuan untuk memilih daerah sampel (hanya sungai, bukan daratan) dan mempersempit piksel yang akan diproses sehingga akan mempersingkat waktu komputasi. Input ROI disediakan di tab input pada aplikasi. Pada tab input disediakan 6 parameter input untuk menentukan bentuk ROI. Tab input ditunjukkan pada Gambar 8.

Setelah ROI ditentukan, selanjutnya data berupa video diekstrak menjadi potonganpotongan frame. Kemudian setiap frame dideteksi keberadaan sampahnya dengan menggunakan metode background subtraction yang menjadikan intensitas warna pada setiap piksel dari frame sebagai sampel distribusinya. Model background dari video akan terus di-update dengan menggunakan metode Gaussian Mixture Model. Sehingga terdapat kemungkinan background pada waktu $t$ tidak sama dengan background pada waktu $t+1$. Foreground (obyek berupa sampah) kemudian akan diperoleh dari proses background subtraction dengan membandingkan setiap frame pada waktu $t$ dengan background pada waktu $t$. Output dari proses background subtraction adalah gambar atau frame dengan 2 jenis warna seperti yang ditunjukkan pada Gambar 2, yaitu hitam untuk background dan putih untuk foreground.

Setelah obyek berupa sampah diperoleh, maka filtering perlu dilakukan. Hal tersebut untuk membantu menghilangkan noise pada frame. Noise

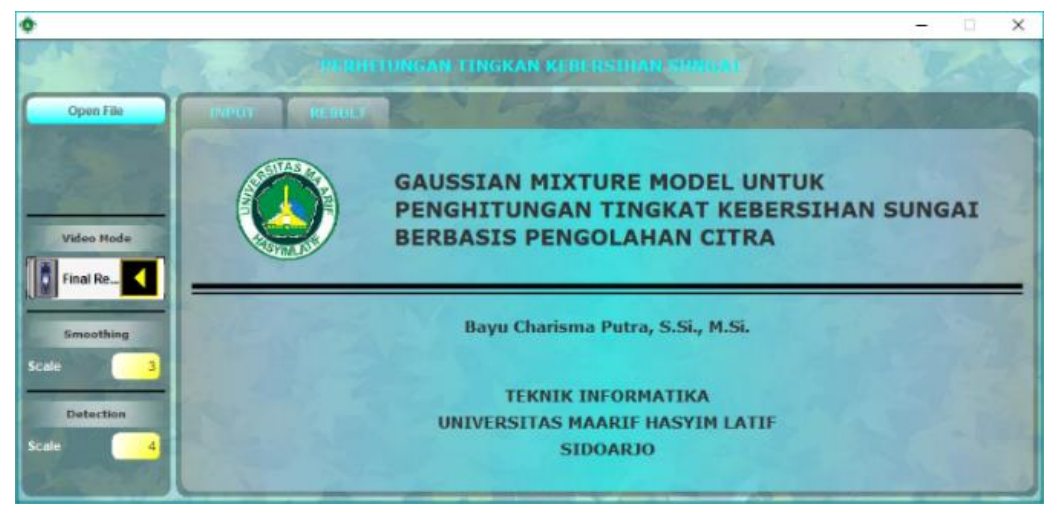

Gambar 7. Tampilan muka 


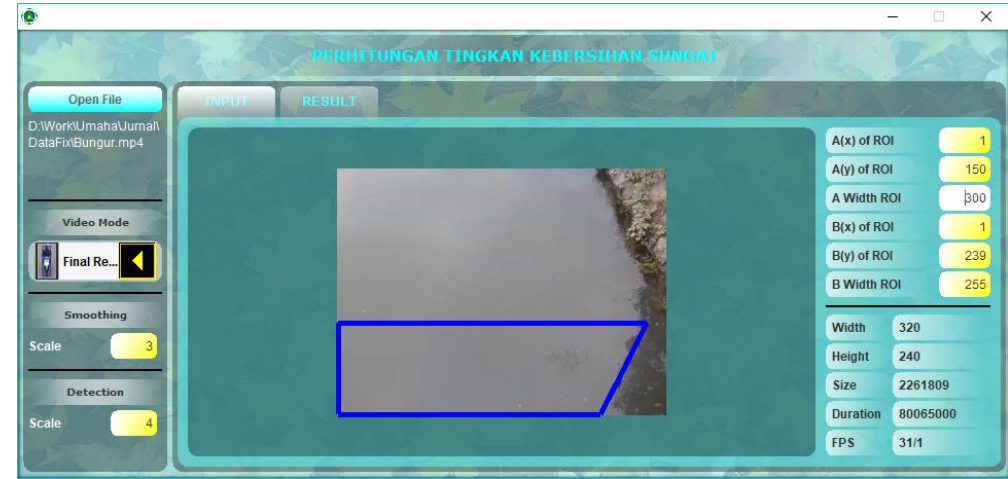

Gambar 8. Tampilan Input ROI

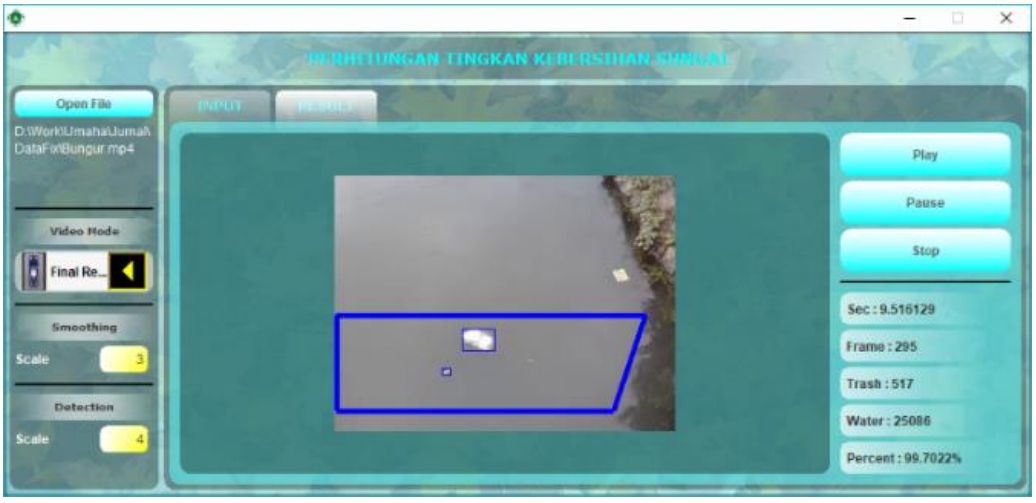

Gambar 9. Tampilan proses
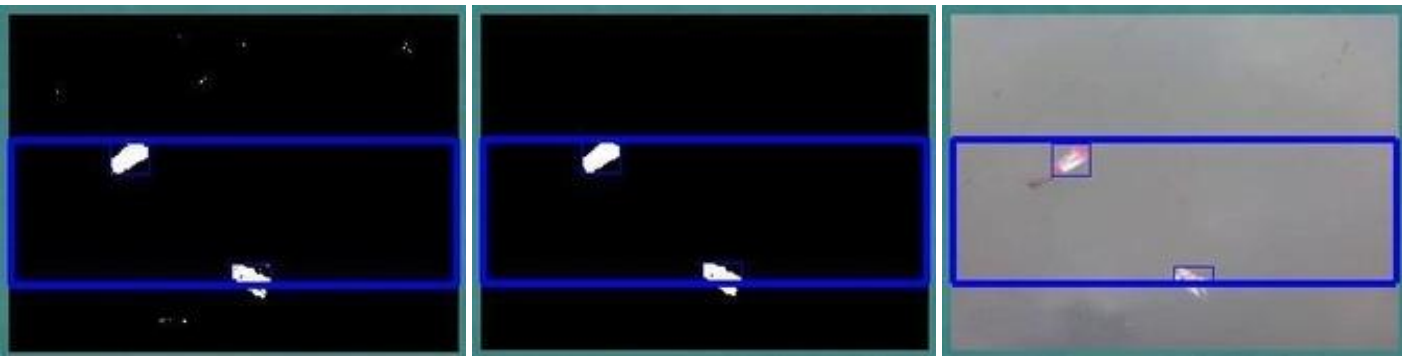

Gambar 10. Output dari tiap proses : Background Subtraction (kiri); Median Filter (tengah); Object Detection (kanan)

yang dimaksud adalah gangguan pada gambar hasil dari proses background subtraction, Seperti air hujan atau serangga terbang. Hasil dari proses filtering berupa frame yang telah dihilangkan noisenya, Sehingga secara visual akan tampak lebih halus.

Setiap frame hasil output dari proses filtering akan dihitung tingkat kebersihannya berdasarkan sampah yang terdeteksi pada area ROI. Satuan dari penghitungan tersebut adalah piksel. Sehingga untuk menghitung tingkat kebersihan perlu diketahui terlebih dahulu jumlah piksel sampah di dalam ROI dan jumlah piksel ROI. Jumlah piksel sampah dan jumlah piksel ROI diperoleh dengan algoritma deteksi obyek seperti yang dijelaskan pada pembahasan sebelumnya. Tampilan interface pada aplikasi dari tahapan perhitungan tingkat kebersihan sungai ditampilkan pada Gambar 9. Sedangkan tampilan interface pada masing-masing tahapan ditampilkan pada Gambar 10.

Perhitungan tingkat kebersihan tiap frame dapat diperoleh dengan menggunakan persamaan (9). Sedangkan tingkat kebersihan keseluruhan diperolah dari rata-rata tingkat kebersihan seluruh frame dari video input.

Tingkat keberihan $=\frac{\text { Jumlah piksel sampah }}{\text { Jumlah piksel ROI }} \times 100 \%$

Data untuk simulasi diambil di tiga sungai kecil yang berbeda, yaitu sungai megare, sungai bungurasih, dan sungai bambe. Dengan menggunakan aplikasi yang telah dibuat data tersebut diinputkan satu persatu kemudian dilihat hasilnya. Hasil dari simulasi ialah

- $\quad$ Sungai Bambe $99.27 \%$

- $\quad$ Sungai Bungurasih 99.81\%

- $\quad$ Sungai Megare 99.8\%

Tentunya simulasi tersebut tidak 100\% akurat dikarenakan banyak yang masih belum bisa 
ter-cover aplikasi, diantaranya adalah sampah yang bergerak di kedalaman, sampah yang warnanya menyerupai sungai dan sampah yang berhenti dan tidak mengalir.

\section{PENUTUP}

Pada hasil dari simulasi yang diambil di tiga sungai, yaitu sungai megare, sungai bungurasih, dan sungai bambe, menunjukkan bahwa sungai di kawasan Universitas Maarif Hasyim Latif masih terdapat sampah yang mengalir di sungai.

Jurnal ini masih bisa dikembangkan lagi karena masih banyak yang belum bisa tercover pada simulasi dari aplikasi seperti yaitu mendeteksi sampah yang berhenti, sampah yang bergerak di dalam air dan perubahan warna yang disebabkan air yang tercemar.

\section{DAFTAR PUSTAKA}

Amaluddin, F., Muslim, M. A., \& Naba, A. (2015). Klasifikasi Kendaraan Menggunakan Gaussian Mixture Model (GMM) dan Fuzzy Cluster K Means (FCM). Jurnal EECCIS, 9(1), 19-24.
Benezeth, Y., Jodoin, P.-M., Emile, B., Laurent, H., \& Rosenberger, C. (2010). Comparative study of background subtraction algorithms. Journal of Electronic Imaging, 19(3), 33003.

Bharti, T. T. (2013). Background subtraction technique review. International Journal of Innovative Technology and Exploring Engineering (IJITEE), 2(3), 166-168.

Hatta, M., \& Susrama, I. G. (2017). Counting Sperma Aktif Menggunakan Metode Otsu Threshold dan Local Adaptive Threshold. Teknika: Engineering and Sains Journal, 1(1), 47-54.

Hatta, M., Susrama, I. G., Purnama, I. K. E., \& Hariadi, M. (2016). Cacah Spermatozoa Menggunakan Background Segmentation dan Boundary Detection. SCAN - Jurnal Teknologi Informasi Dan Komunikasi, 11(1), 67-74. 